\title{
The visual character of colonial housing in Palembang Case study: Colonial housing settlement of Talang Semut in Palembang
}

\author{
Muhammad Fajri Romdhoni ${ }^{a^{*}}$, Hendi Warlika Sedoputra ${ }^{a}$ \\ ${ }^{a}$ University of Sriwijaya, Inderalaya $\mathrm{km} 32$, Indonesia \\ *Corresponding author. Tel.: +62 818 202625; fax: +62 711313233 \\ E-mail address: muhammadfajriromdhoni@gmail.com
}

\begin{abstract}
Palembang, having been one of the oldest city in Indonesia has inherited buildings that define an era. One of those remains are the traces of the colonial buildings in Palembang. The buildings that were built in those era are very predominant to it's surrounding. The old Palembang area is divided with the 16 ilir in Palembang is an economic sector and the merdeka corridor is the government sector and also the Talang Semut area as a housing and settlement sector. This paper is about the traces of colonial building in the old colonial building in Palembang, represented with the Talang Semut area that have transformed into commercial places. The methods used in this study are using a visual research study to pinpoint the existing nature of the building and the transformation of the buildings as a result of changes in buildings function from settlements into micro commercial areas and also using space syntax analysis as a quantitative method to see how the streets have effected the transformation of the buildings. The transformation of Dutch and colonial places are found many in the colonial settlements in the city of Indonesia and have shaped the vibrant colors of cities in Indonesia. The Talang Semut area acts as one of the areas that transformed from settlements into micro economic, such as stores and culinary spots. The transformation of function have very much affected the visual expression of its original facade and therefore affected the character of the colonial housing settlements of Talang Semut in Palembang.
\end{abstract}

Keywords: settlements; visual research; transformation; character

\section{Introduction}

As the oldest city in Indonesia, Palembang city has inherited many heritage buildings and sites which represented various era's in Palembang, stated from the kingdom of Sriwijaya and also the rise of the Palembang Darrussalam as well as the Dutch and colonial settlements in Palembang. With strong background of heritage Palembang city hasn't been very preserving to its heritage background. As many other heritage cities in Indonesia, the well preserve area were the building hat were created during the Dutch colonies in Indonesia. This Paper is about the identification and transformation on the early settlements in Palembang that has undergone changes from the settlements into commercial facilities. The selected site is the Talang Semut area that originated from the high society areas of Dutch settlements in Palembang. The Kambang Iwak Besak and Talang Semut area were the early settlements as a cluster of housings and holds a drainage body of water or pool that acts not only as a storm drain but also as a public space. Having had developed as a colonial housing, the area has transformed into one of the greenest area of the city, thus making the area into a destination for the people of Palembang for social activities such as jogging, hangouts and also recreational activities. 
The diversity of activities attracts people and as the activities progress so does the needs resulting in the changes of facade as a demand for identity of a commercial facilities. The changes results in the transformation of the character of Talang Semut from Dutch and colonial settlements with it's heritage building into a more eclectic and modern façade with it's more contemporary look. In some way, changes are good but unplanned changes that are going out of control could end into an uncontrolled transformation. The need to preserve the uniqueness is very important. The uniqueness will be a dominant factor to distinguished between areas and the identity of a location (Lynch, 1960). The phenomenon and transformation occurring in the Kambang Iwak Besak is the reason in need of guidelines for the development in the area. The development that holds the characteristic of the building will result in the continuation of characteristic of Talang Semut Area

\section{Research Theory and Methods}

\subsection{Visual Character and Space Syntax}

The research is conducted to create a visual research method on colonial housings especially in the kelurahan Talang Semut area.
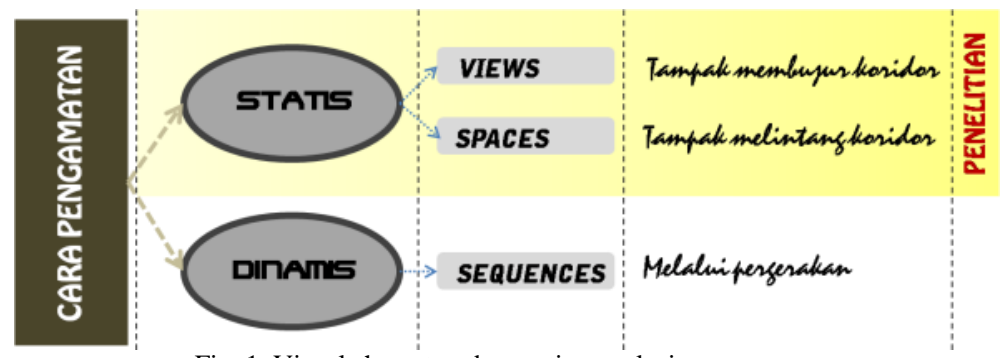

Fig. 1. Visual character observation analysis.

The methods of research is being taken to observe the static and also dynamic in spatial character. the static observation is to recognize the shape, lines, scale and also space between the building whereas the dynamic observation are being carried out to observe the pattern, alignment, skyline and also various shape and sizes in the buildings. The 4 elements of dynamic observation are to identify the basic spatial relations between buildings (Berry, 1980).

In addition to the theory of Greater London Council (GLC, 1978) study in "an introduction to housing layout" stated the elements to create the spatial façade or covering of buildings are walls, street and also vegetation as roof of the streets. The elements that shaped the visual characteristics of an area are also divided into the primary space stated by the hard surface materials such as building walls and trees as a spatial element of an area. The secondary elements are fences, parking spaces, pedestrian space that also shaped the physical elements of visual character of an area.

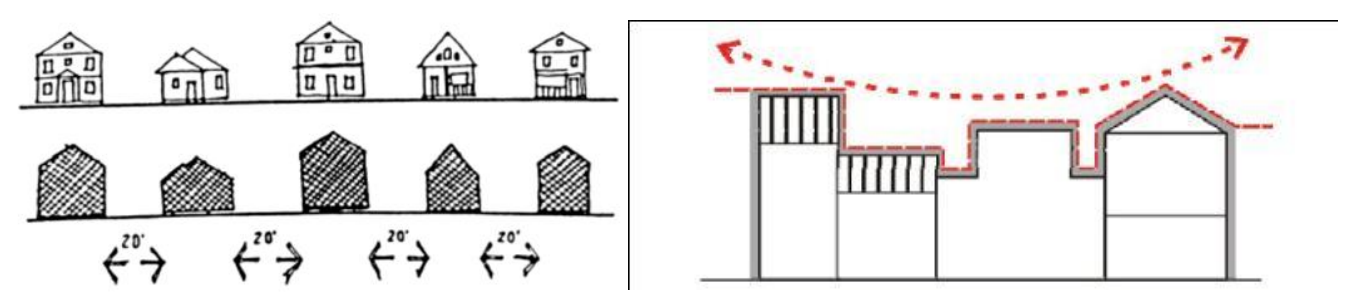

Fig. 2. Building row, pattern and skyline analysis. 

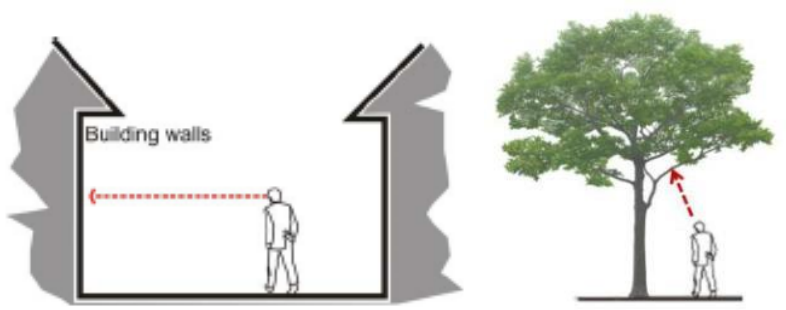

Fig. 3. Buildings as spatial walls and trees as spatial elements

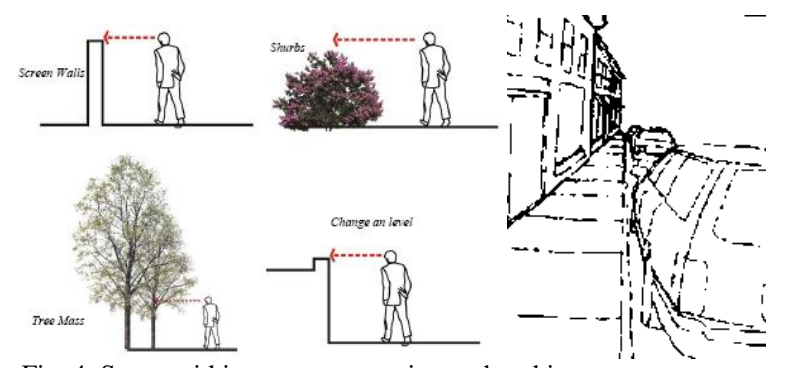

Fig. 4. Space within space; vegetation and parking on street.

Space syntax is being used as the dynamic and sequence way of observation and it is a method to describe and analyze the relationship between inner void in urban areas and the relationship are described as layouts. The social logic of space (Hillier \& Hanson, 1984) space syntax is a technique to visualize, measured and also calculated the configuration of space and how to analyze and define it.

According to Stonor (2011) there are 3 ways on analyzing the space theory on space syntax using the UCL depthmap application:

1. An axial / segment analysis is the use to analyze the area of large scale such as roads in cities etc. it is an analysis of relationship between the circulation segments within a city and its relation to the movement, land value and also social activity. The axial and segment difference are the use of matrix measurement and segment measurement using depth.

2. VGA (Visual Graph Analysis), are being used in a smaller scale for spaces in buildings. VGA analysis used isovist that could pinpoint the visual areas of space and calculate the movement of pedestrian and also social interactions.

3. Agent analysis, used to analyze building and the human movement simulation in space.

\subsection{Visual Character elements}

Visual character assessment is being taken by the physical elements in the area through static observations by a strand of views with the object and analyzing the frontal corridor and created spaces and also the cut out section of buildings and corridor. By analyzing the views thus can results of dominance by the physical elements and we can point out the contrasting elements that are being created in an area. The diversity, continuity, the intactness and also the unity of physical elements, by analyzing each elements therefore we can emphasize the sequence and uniqueness of an area.

The correlation between space and section of corridor is shown on the proportion of space between buildings. It shows $\mathrm{D} / \mathrm{H}=1,2,3$ are common used in the housing settlements. $\mathrm{D} / 4$ are being used to make a more private quarter and the integration between buildings is reduced. $\mathrm{D} / \mathrm{H}<1$ are more common being used in slum areas where the interaction between buildings are so dense and create problems for the physical qualities to the building such as the quantity of light and air creates more issues to the building. 


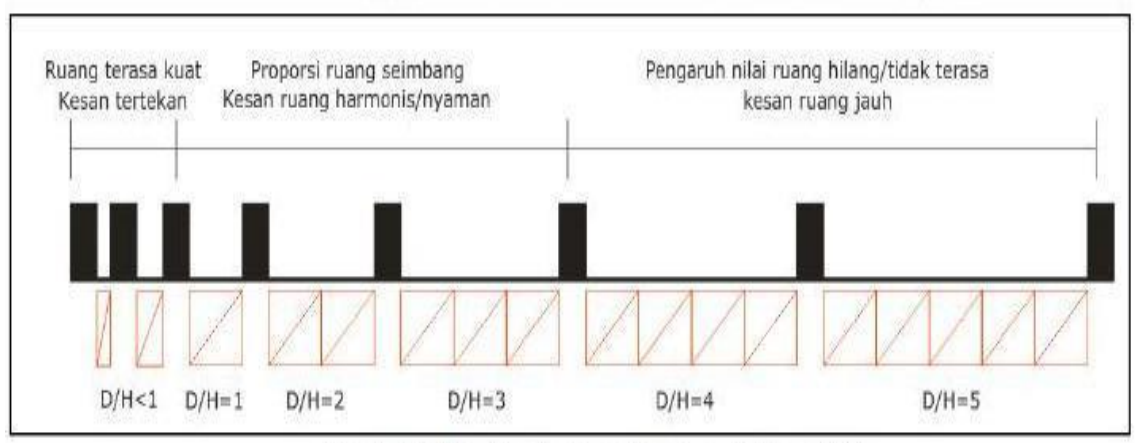

Fig. 5. Ashihara enclosure qualities and spatial behavior.

The urban design compendium also explains the form and use of enclosure and spatial development. The development of spatial form should contribute to spatial character of an area and the consistency of enclosure would create the quality of visual character of an area.

Table 1. Height and width ratio.

\begin{tabular}{ccc}
\hline & Maximum & Minimum \\
\hline Mews & $1: 1.5$ & $1: 1$ \\
Streets & $1: 3$ & $1: 1.5$ \\
Squares & $1: 5$ & $1: 4$ \\
\hline - & Mews; a row or street of houses and creates a and order of path \\
- Streets; a public road in a city or town, typically with houses and buildings on one or both sides \\
- Squares; spatial area created as an open space
\end{tabular}

\section{Results and Discussion}

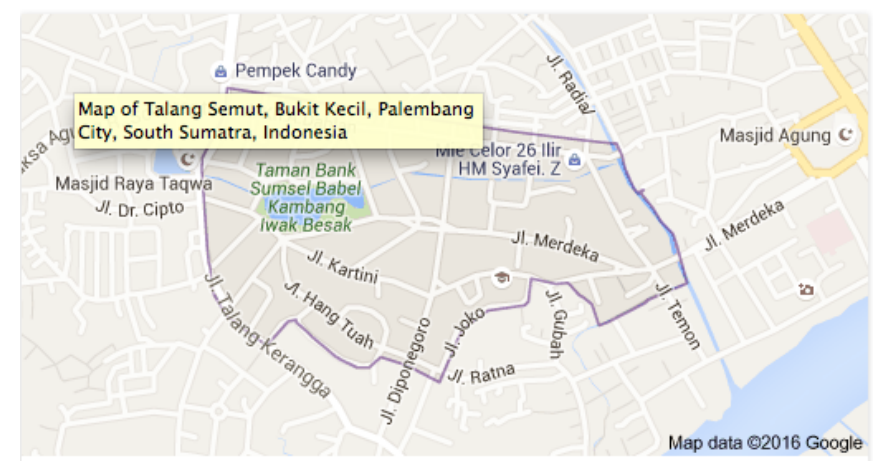

Fig. 6. Talang Semut area in Palembang.

Tiling Semut is one of the early housing settlements in Palembang and area a section of kelurahan in Palembang. The architecture distinctiveness of Talang Semut is that the use of colonial housing and also the use of limasan roof as an identitity of building in Palembang. Being an old part of the city, it has transformed into a vibrant area and a destination of both local and tourist making the area into one of the must visit areas in Palembang. This research is focused on the Kambang Iwak an open space and act as a centerpoint of Talang Semut area, which is now being transformed not only as a housing settlement but also into a commercial space.

With the observation, the main streets of Kambang Iwak in Palembang are the 3 main roads that is Jalan KH. Ahmad Dahlan in the north side, Jalan DR. Sutomo in the east side and Jalan Tasik - Jalan Indra in the south side Kambang Iwak area. The main development of the area was dominant with private housings and colonial style 
houses. Nowadays, the main function had shifted into commercial buildings into café's, restaurants and other commercial functions. The transformation of functions can be analyzed with UCL depthmap regarding the visual graph analysis. The UCL depthmap shows the visual integration on the main street of Kambang Iwak Besak area of Palembang, which the red area or the lighter color shows the dominant visual integration and the blue area or the darker color shows the less integrated areas.

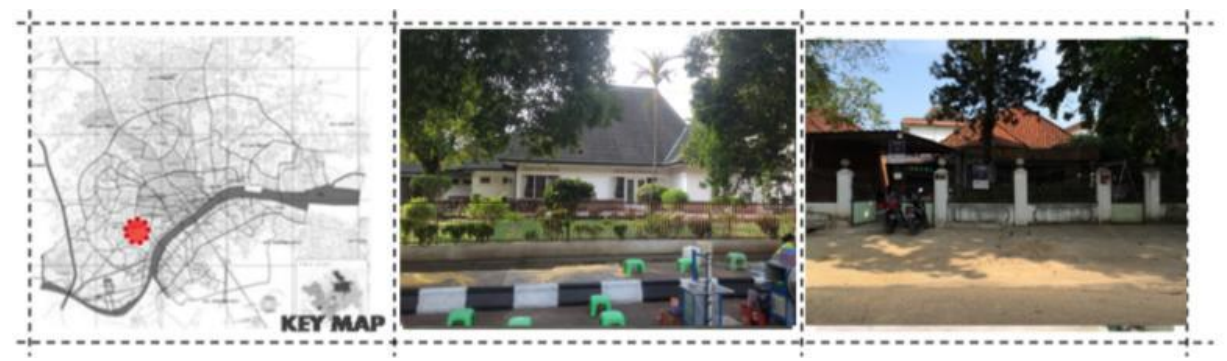

Fig. 7. Elite colonial housing, Talang Semut Palembang.

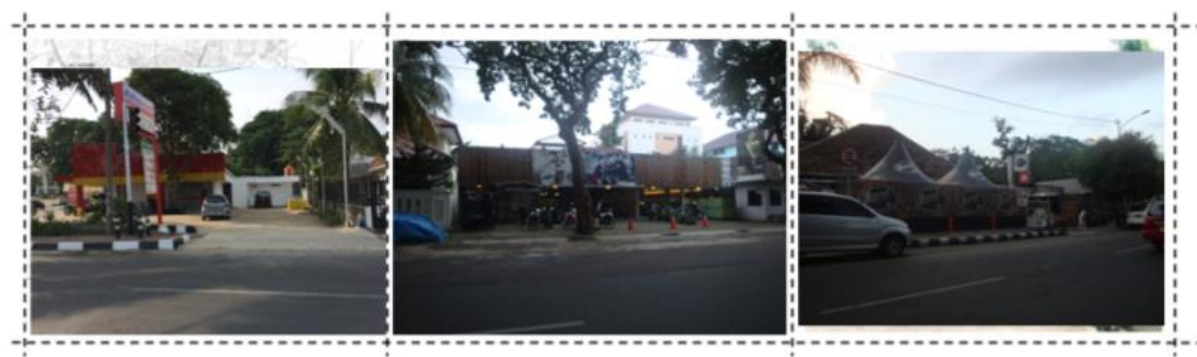

Fig. 8. changes of function and façade in kambang iwak besak.

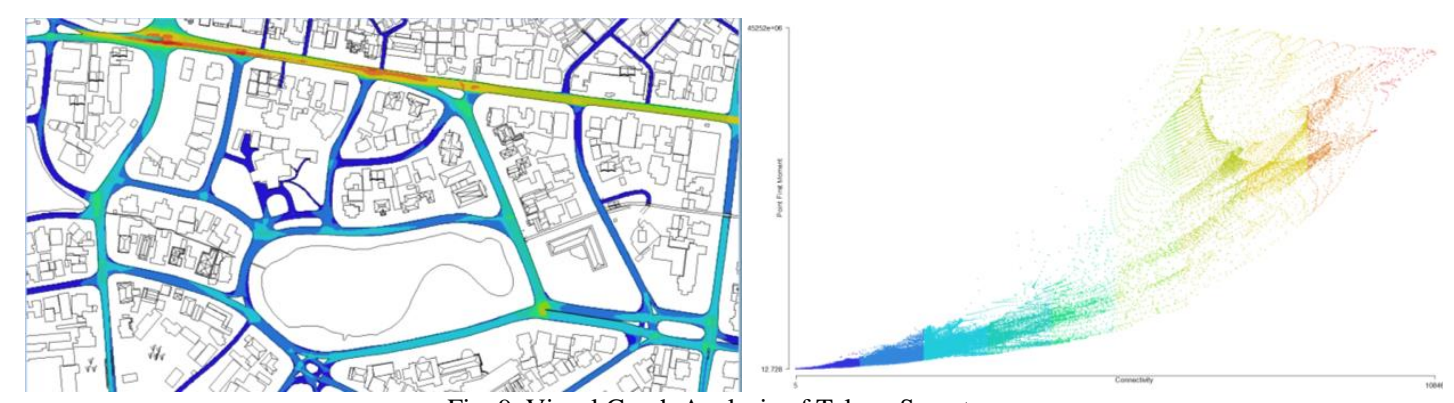

Fig. 9. Visual Graph Analysis of Talang Semut area.

Space syntax is being used as a visual graph analysis / VGA that shows the colors of potential of visual integration on the Kambang Iwak Besak area. The color variation shows gradation of colors which indicates - dark blue - light blue - green - yellow - orange - red). The gradation of colors shows the potential of visual integration. The blue color shows that spatial space area that are more closed whereas the red color shows areas that are more integrated. The graph above shows that the more integrated areas tend to change the function from housings into commercial while the darker area tend to stay to its original function as private housings. The preliminary graph clearly shows that $\mathrm{Jl}$. KH Ahmad Dahlan is more dominant in visual integration resulting that the area transformed more rapid than the other streets in the area.

The graph shows spatial analysis data of the Talang Semut area of kambang iwak Palembang. This research specified the corridor into 3 main roads of J1 K.H. Ahmad Dahlan, J1 Dr. Sutomo and Tasik street as a representative of the area. 

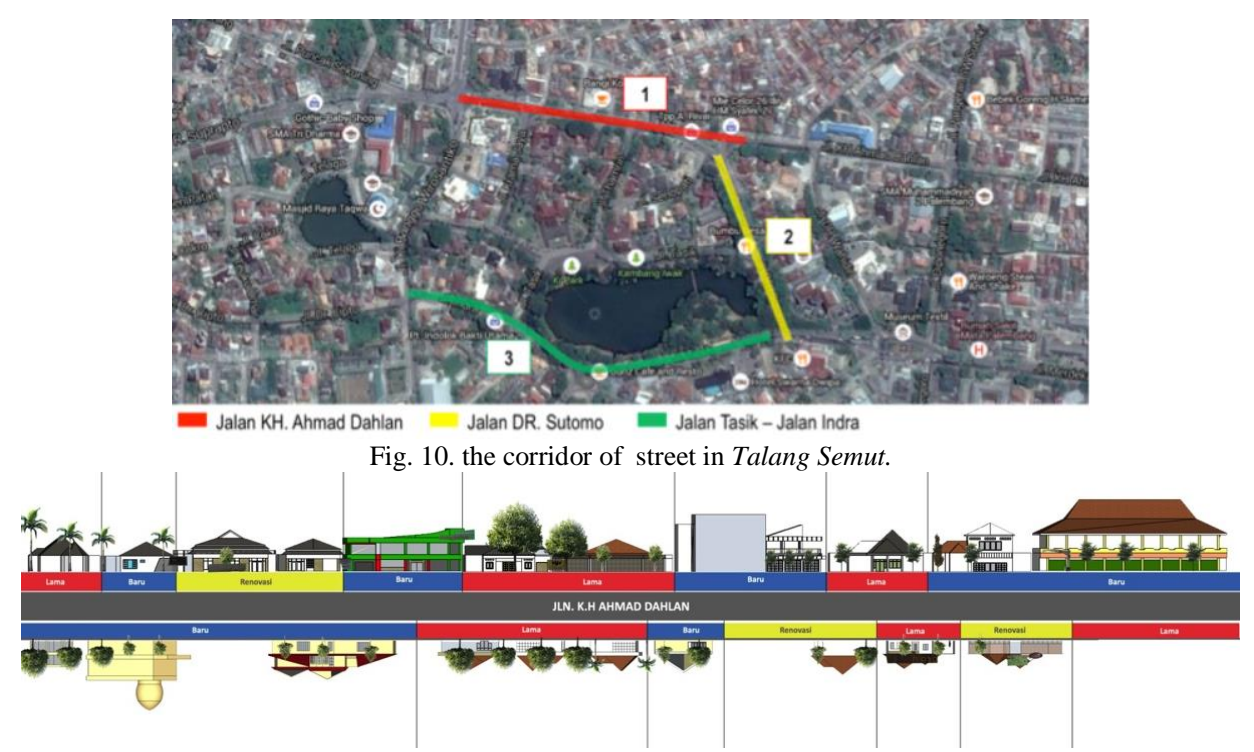

Fig. 11. Serial view koridor K.H. Ahmad Dahlan street.

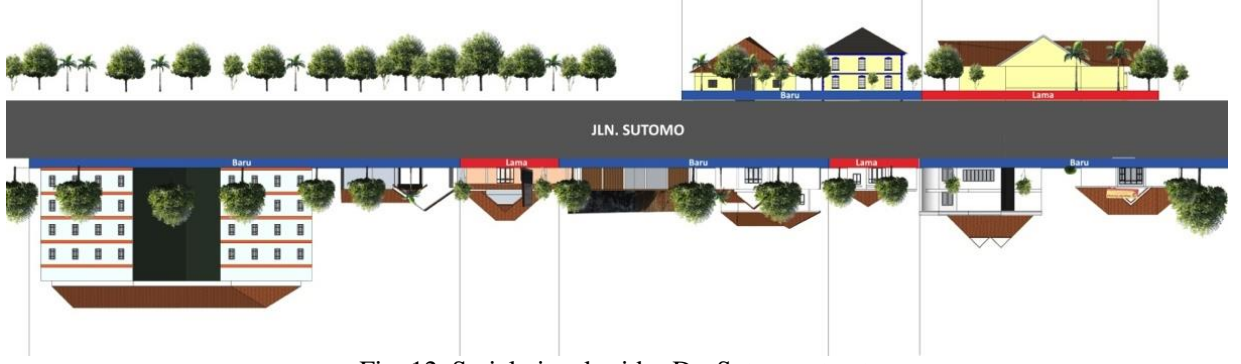

Fig. 12. Serial view koridor Dr. Sutomo street.

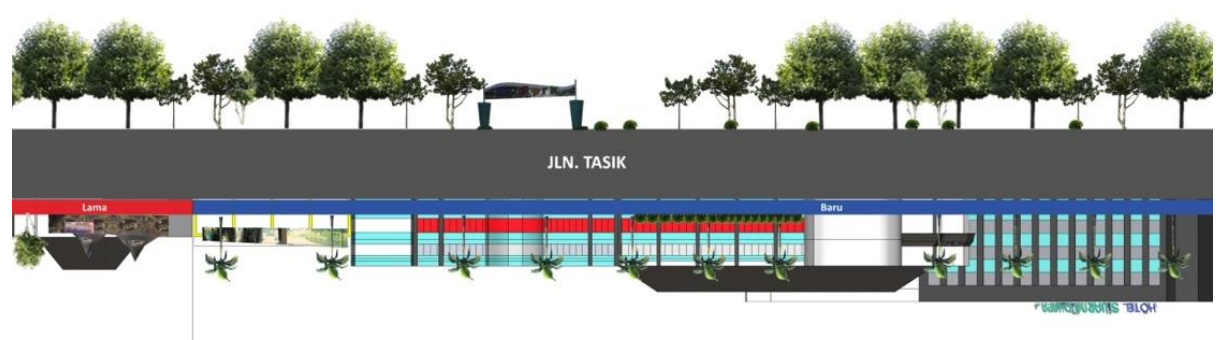

Fig. 13. Serial view koridor jalan Tasik street.

By analyzing the serial view of each corridor in Talang Semut area we could see that the enclosure qualities and spatial behavior shown in Figure 5 gives us insight on the difference of features in each street. We could clearly see that the Jl KH Ahmad Dahlan is much more dense with while the Jl Sutomo is less dense and Jl Tasik consist new and larger buildings.

This research continues by identifying Kelurahan Talang Semut area of J1 KH Ahmad Dahlan to J1 Dr. Sutomo street holds 55 unit of buildings in it's corridor. The percentage consists of $31 \%$ of old buildings, $20 \%$ are renovated buildings and $49 \%$ are new building that is a result of the fast changing in functions in the area. The identification of the area shows that there is a lot of original buildings were either demolished or being adaptive reused onto commercial buildings, to meet the transformation needs of the kambang iwak area. 


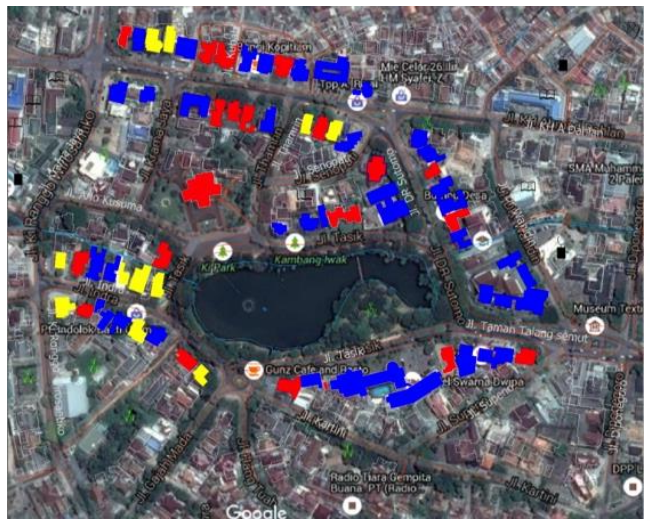

New Buildings

- Old Buildings Renovated Buildings

Fig. 14. Building age mapping.

Table 2. Building age data of Kambang Iwak area.

\begin{tabular}{|l|c|c|c|c|c|c|c|c|c|}
\hline & $\begin{array}{c}\text { Street } \\
\text { corridor }\end{array}$ & $\begin{array}{c}\text { Jl. KH. Ahmad } \\
\text { Dahlan }\end{array}$ & \multicolumn{2}{|c|}{ Jl. DR. Sutomo } & \multicolumn{2}{c|}{$\begin{array}{c}\text { Jl. Tasik - Jl. } \\
\text { Indra }\end{array}$} & \multicolumn{3}{c|}{ TOTAL } \\
\hline Building age & Qty & $\%$ & Qty & $\%$ & Qty & $\%$ & Qty & $\%$ \\
\hline Old buildings & 8 & 35 & 3 & 27 & 6 & 29 & 17 & 31 \\
\hline Renovated buildings & 4 & 17 & 0 & 0 & 7 & 33 & 11 & 20 \\
\hline New Buildings & 11 & 48 & 8 & 73 & 8 & 38 & 27 & 49 \\
\hline
\end{tabular}

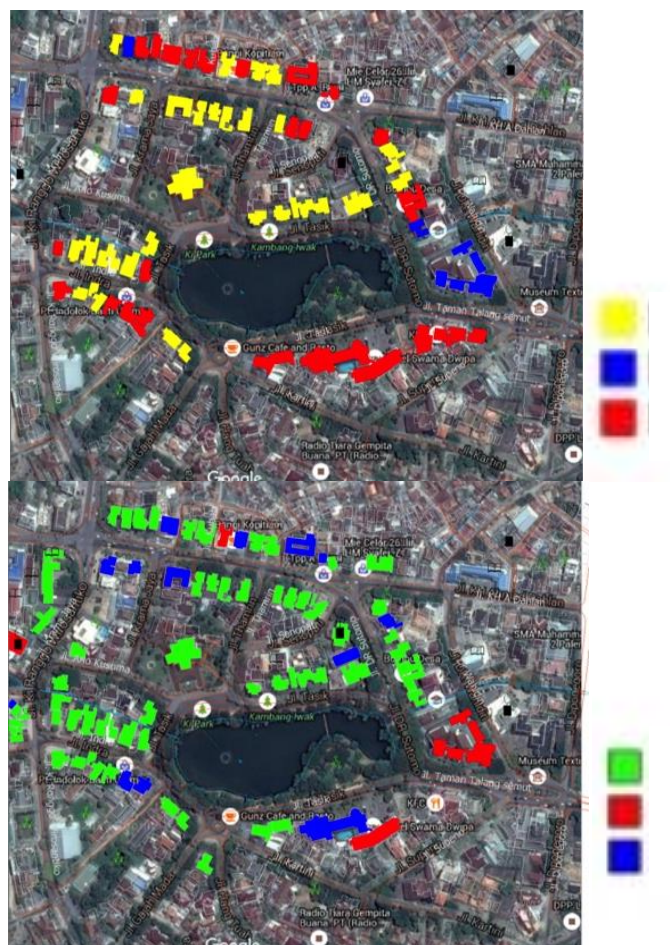

Housing

Office

Commercial

Fig. 15. Building function map and building height mapping.

1 storey building medium rise building 2 storey building 
From the three identified street corridor, the research founded that there are 28 buildings or a mere of $51 \%$ of buildings stayed to it's original function as private housings, 3 units or 5\% transformed into small office and 24 other units or $44 \%$ of the original buildings has transformed into commercial spaces.

\begin{tabular}{|l|c|c|c|c|c|c|c|c|c|}
\hline & $\begin{array}{c}\text { Building } \\
\text { age }\end{array}$ & \multicolumn{2}{|c|}{ Old } & \multicolumn{2}{|c|}{ Renovated } & \multicolumn{2}{c|}{ New } & \multicolumn{2}{|c|}{ TOTAL } \\
\hline $\begin{array}{l}\text { Babilding } \\
\text { Function }\end{array}$ & & Qty & $\%$ & Qty & $\%$ & Qty & $\%$ & Qty & $\%$ \\
\hline Housing & 9 & 53 & 4 & 36 & 10 & 37 & 23 & 41 \\
\hline Commercial & 6 & 35 & 7 & 64 & 13 & 48 & 26 & 47 \\
\hline Office & 0 & 0 & 0 & 0 & 3 & 11 & 3 & 6 \\
\hline Others & 2 & 12 & 0 & 0 & 1 & 4 & 3 & 6 \\
\hline
\end{tabular}

The research also conducted to identify the height of each building in the area. The identification indicates 14 single story buildings. The majority of the buildings in the area remains to its main function as a private housings, and there are a few new buildings that were renovated into 2 story buildings to meet the new commercial functions and also the new buildings is mainly mid rise buildings to accommodate the new function of the building. The research outcome and the correlation between the buildings age, function and height shows that the old buildings tend to stay with it's original function as a private house and rarely renovated into mid rise buildings where the renovated ones tend to change the buildings function to commercial use such as restaurants, café and other commercial uses. The new building is diverse into multiple of function but mainly focused on the building floor coverage area to maximize the buildings floor ratio.

In general the visual character of kelurahan Talang Semut area was shaped by the distinctiveness of colonial housings. The character of the buildings form an image of the area and also the shape of the streets and the positions of its buildings with large trees in the pedestrian streets also form a specific character to the area. The buildings were shaped a spatial dominance and shaped the corridor of the streets. These are the elements that shaped each corridor as a sample of kelurahan Talang Semut area.

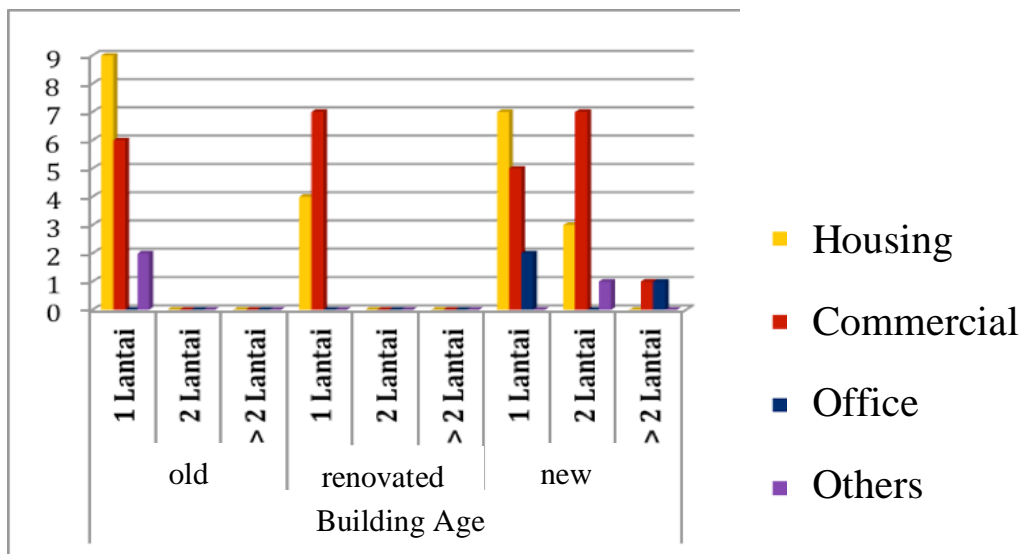

Fig. 16. Age, function and height correlation between buildings. 


\section{Building}

In general the transformation of buildings in the street of Talang Semut area doesn't differs very much, and in this paper the researcher took KH Ahmad Dahlan street as a sample of transformation because the highlighted street were transformed very rapidly. The transformation corresponds to the visual graph analysis that shows the Jl KH Ahmad Dahlan are among the most visually integrated areas in kelurahan Talang Semut. The visual character of the building can be described by the height of the buildings, the form and shape, the development pattern and also solid void fasade along the KH Ahmad Dahlan Street.

- Old Building : holds a distinctive colonial style one story building. That has character in lines, the shape of roof, the geometrical shape of the houses and also the triangular shape of limasan roof as an adaptation to the Palembang style architecture. The old house is a single function building and has a balance and proportion of solid void of the building forms

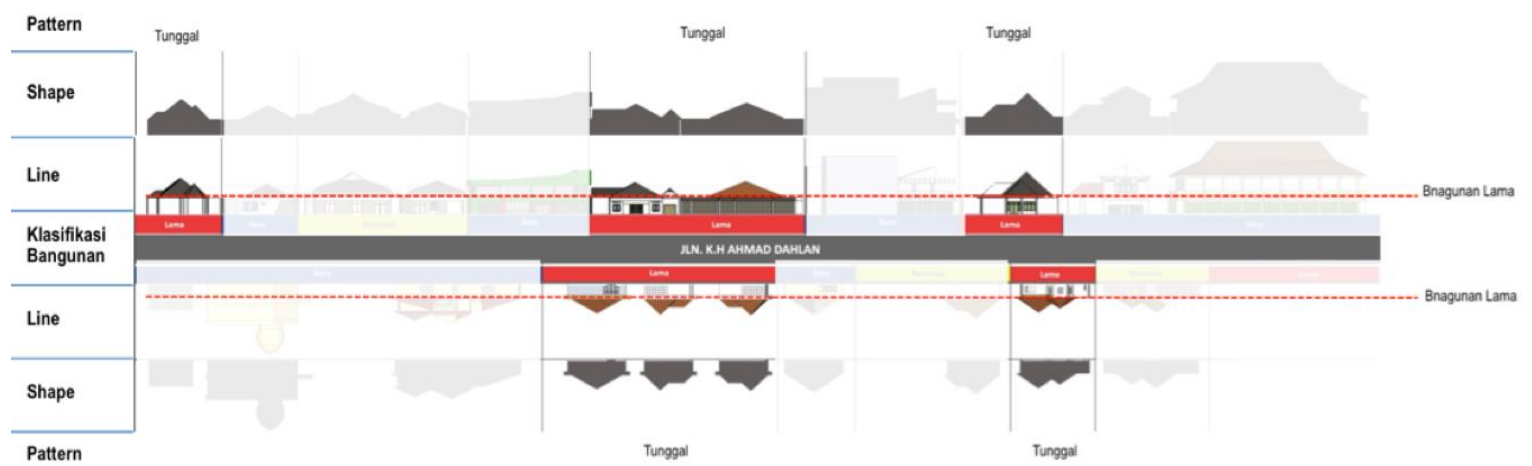

Fig. 17. Old building character koridor K.H. Ahmad Dahlan.

- Renovated Building : the buildings being renovated are transformed building into commercial space on a more contemporary style architecture. Some of the redesigned buildings are well balanced between the old an new regarding the distinctive feature of the building such as the triangular shape of the roof and the geometrical shape of the colonial style architecture. The renovated houses are more design to optimize the existing building to accommodate the new commercial functions.

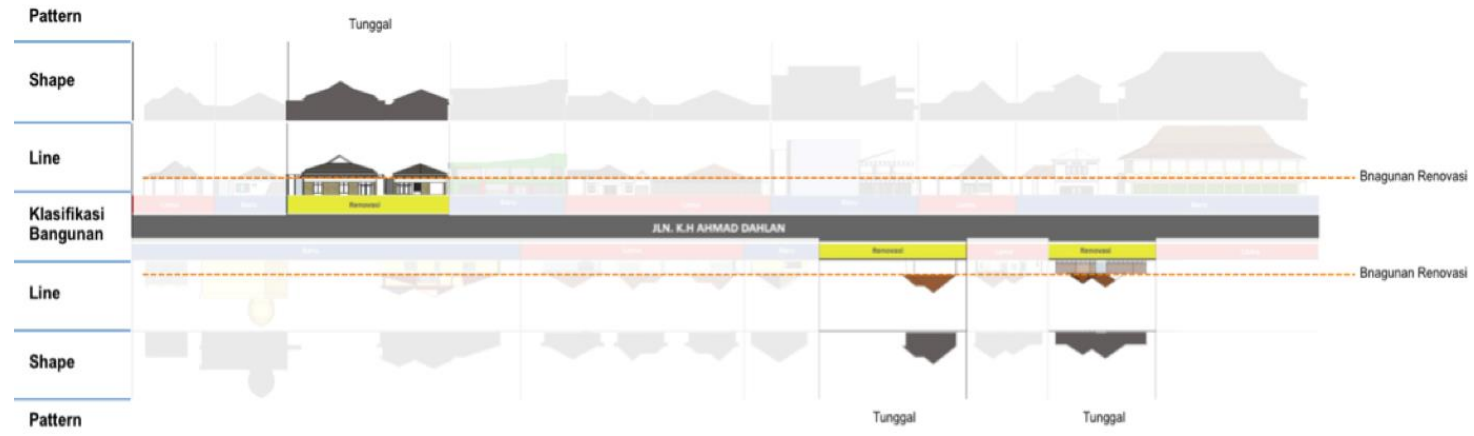

Fig. 18. Renovated building character koridor K.H. Ahmad Dahlan.

- New Building: are more detached in visual character from the buildings in the area, with 1-4 story high, the shape are more rectangular shape dominant and also adopting the limasan style of roof. The building holds a 
variety of function not only commercial buildings but also office buildings. The building tends to be under designed and visually different from the character of the older buildings in the area.

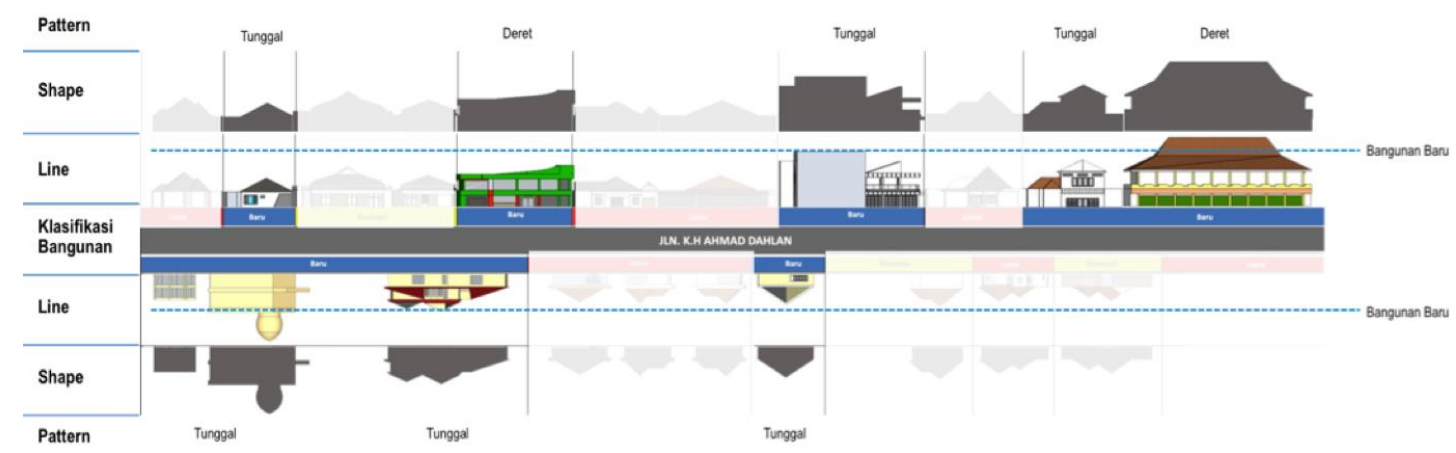

Fig. 19. New building character koridor K.H. Ahmad Dahlan.

\section{Conclusions}

Visual character of colonial housing in Talang Semut Palembang with the case study of housing settlements in results that the original visual character had been transformed and the visual integration had been abrupt. The space syntax method is mainly used for the Visual Graph Analysis to view the area that has bigger potential to change due to its high integration of space. The visual character in this study is being transformed mainly into commercial space and office. The reasons of the transformation were caused by the following reasons:

- The renovated buildings are being transformed into commercial buildings by the rapid growth of the city. Transformation into a more economic space has influenced the change in the urban fabric of the city but the transformation are not being followed by the quality of design and development causing the change in balance of the visual character of the old colonial housing in Talang Semut area.

- The new buildings could play a vital role in preserving the visual character of Talang Semut area by being design regarding the role of visual character and preserve the image and identity of Talang Semut area.

- The dominance of commercial spaces and office with individual branding and style regarding from the style of view whereas the new building are much taller than the old buildings and the difference in geometrical shape and tend to be design in row houses or more known as ruko or the shop houses. The character shown from the space also differentiate between the old buildings and the new ones where the setbacks of the old colonial housings are being cut down and the new building tend to go more towards the road to maximize the floor ratio of the site.

The physical elements of buildings played a pivotal role on diminishing the visual character of an area. The signage and also form and shape of the building should follow a code of design to preserve the visual character of the colonial housing and enhancing the image and character of Talang Semut area in Palembang.

\section{References}

Berry, W. (1980). Good neighbors : building next to history - design guidelines handbook. Denver: Colorado Historical Society. GLC. (1978). An introduction to housing layout : a GLC study. USA: Architectural Press.

Hillier, B., \& Hanson, J. (1984). The social logic of space. Cambridge: Cambridge University Press. https://doi.org/10.1017/CBO9780511597237 Lynch, K. (1960). The image of the city. MIT Press. 